\title{
Performance, Carcass and Bone Characteristics and Histological Structure of Some Organs of Broilers fed Inorganic or Organic Trace Mineral Premix
}

\author{
Hussein Hassan ${ }^{1}$, Ahmed Samy $^{1}$, Amani Youssef ${ }^{1}$, Nafisa Abd El-Azeem ${ }^{1}$, Mahmoud Madkour ${ }^{1}$, \\ Osama Aboelazab $^{1 *}$, Mohamed Shourrap ${ }^{2}$ and Mohamed A Mohamed ${ }^{1}$ \\ ${ }^{1}$ Animal Production Department, National Research Centre, Dokki, 12622 Giza, Egypt \\ ${ }^{2}$ Poultry Production Department, Faculty of Agriculture, Ain Shams University, Shoubra El-Kheima, 11241 Cairo, Egypt \\ *Corresponding author: os_azab@yahoo.com; om.aboelazab@nrc.sci.eg
}

\begin{tabular}{l} 
Article History: $21-373 \quad$ Received: 13-Aug-2021 Revised: 10-Sep-2021 Accepted: 13-Sep-2021 \\
A BSTRACT \\
Effect of using inorganic and organic trace minerals premix on performance, carcass, and tibia bone characteristics and \\
histological structure of ileum, liver, and tibia bone of broiler chicks were investigated. A starter (1-21 d) and a grower \\
(22-35 d) corn-soybean meal diets were supplemented with inorganic trace mineral premix ITM (T1), organic trace \\
mineral premix OTM (T2), or ITM+OTM (T3). The organic mineral premix had lower element concentrations than the \\
inorganic premix. A total of 150 one-day-old Arbor Acres broiler chicks were distributed into three dietary treatments \\
(5 replicates x 10 chicks each). The results showed no significant effect of dietary treatments on broiler chickens' body \\
weight gain and feed intake. Birds fed organic trace minerals showed a significantly better feed conversion ratio than \\
inorganic trace minerals. Organic trace minerals did not significantly affect carcass characteristics or tibia bone \\
measurements except tibia ash\%. Histological analysis of ileum revealed that broiler chicks fed diets with organic \\
minerals significantly decreased villi length and crypt depth. The liver tissue and tibia bone were healthy and normal in \\
all experimental groups. It could be concluded that organic trace minerals can be used at lower levels than the \\
recommended levels of inorganic trace minerals not only without a negative impact on performance but may lead to \\
improve feed efficiency and intestinal and bone histology. Further studies, using other parameters, are needed to prove \\
the impact of different organic minerals sources and levels upon poultry production and environmental pollution. \\
\hline Key words: Organic mineral, Performance, Bone parameters, Broilers. \\
\hline
\end{tabular}

\section{INTRODUCTION}

Commercial poultry production is highly advanced and many feed additives could be used to improve the productivity of birds. Recently, organic trace minerals have gained more attentions because of its importance in broiler diets to ensure better health and production (Nys et al. 2018; Alagawany et al. 2021). Zinc, manganese, and copper are trace minerals that play key roles in biological functions and are required to stay alive and promote optimal health (Dieck et al. 2003). Minerals support bone structure and are involved in a variety of enzymes, hormone secretion pathways, and immunological defense mechanisms. Most trace minerals are widely supplied in commercial poultry diets in the form of inorganic salts, such as sulphates, oxides, and carbonates, to provide mineral levels that prevent clinical deficits and allow the birds to achieve their genetic potential for growth (Sirri et al. 2016). NRC (1994) specifies $\mathrm{Zn}: \mathrm{Cu}: \mathrm{Mn}$ requirements for broilers as 40:8:60mg/kg. However, because of limited bioavailability of inorganic form, commercial nutritionists always provide inorganic trace elements at double this level in the broilers diet. So, the physiological requirements of the birds are covered by a low portion of these levels and the majority of trace mineral supply is excreted into the environment (Nys et al. 2018).

Organic minerals are chelating agents that help in better feed absorption and utilization in the body tissue. Using organic trace minerals at lower levels for animal diets have been suggested based on the hypothesis that such form of minerals has a higher bioavailability than inorganic form, and hence provides better immunity (Ghasemi et al. 2020). Any mineral that is bound to organic compounds is considered an organic mineral, regardless of the type of existing bond between mineral and organic molecules.

Several researchers have studied the efficiency of organic minerals on broilers performance at lower addition levels (Nollet et al. 2007; Zhao et al. 2010; Arif et al. 2019).

Cite This Article as: Hassan H, Samy A, Youssef A, El-Azeem NA, Madkour M, Aboelazab O, Shourrap M and Mohamed MA, 2022. Performance, carcass and bone characteristics and histological structure of some organs of broilers fed inorganic or organic trace mineral premix. International Journal of Veterinary Science 11(2): 207-214. https://doi.org/10.47278/journal.ijvs/2021.097 
Reduction of mineral excretion in environment could be achieved via lowering the amounts of minerals supplemented in birds' diets through using organic form without affecting birds' productivity (Leeson and Caston 2008; Madkour et al. 2015). Inclusion of organic trace minerals in broiler diets had a significant effect on feed conversion ratio (FCR) when compared to inorganic minerals but not on growth performance (Burrell et al. 2004). Also, improvements in live body weight and FCR could be achieved as results to using organic trace minerals completely in broilers' diets when compared to using the inorganic form (Sirri et al. 2016). Bortoluzzi et al. (2020) reported that organic minerals have a higher resistance to $\mathrm{pH}$ changes in the gastrointestinal tract of birds. This led to more digestibility, better performance, and less excretion of these minerals (Figueiredo Júnior et al. 2013). Organic minerals addition in broiler diets through the $7^{\text {th }}$ day of age till the end of the $4^{\text {th }}$ week of age showed a better growth performance than using the inorganic form (Baloch et al. 2017). Moreover, Carvalho et al. (2018) found that inclusion levels of 50 and $75 \%$ of organic trace minerals to broiler diets led to lower excretion levels of trace minerals and slightly improved growth performance.

Thus, the aim of this study was to compare the effects of organic and inorganic trace minerals supplementation on growth performance, carcass and tibia bone characteristics and histological structure of ileum, liver and tibia bone of broiler chickens.

\section{MATERIALS AND METHODS}

\section{Experimental Design and Management}

Corn-soya bean meal basal starter (1-21 days) and grower (22-35 days) diets were formulated to meet the nutrient requirements as reported in chick management guide. 150 one-day-old Arbor Acres broiler chicks were divided into three experimental groups of 5 replicates (10 chick/replicate), each. The formulation and nutrient composition of the experimental diets are shown in Table 1. Diet 1 supplemented with ITM premix at $1.5 \mathrm{~kg} /$ ton of feed (T1); diet 2 supplemented with OTM (methioninechelated trace minerals) at $0.5 \mathrm{~kg} /$ ton (T2), while diet 3 supplemented with ITM premix at $0.75 \mathrm{~kg} /$ ton and OTM premix at $0.25 \mathrm{~kg} /$ ton (T3). Table 2 shows the levels of inorganic and organic trace minerals used in the experimental diets. Birds were raised in a warmed brooder house and fed the dietary treatments from 1 to 35 days of age. Feed and water were allowed ad libitum consumption. A vaccination program against $\mathrm{AI}, \mathrm{ND}, \mathrm{IB}$ and $\mathrm{IBD}$ was adopted throughout the experimental period.

\section{Sampling and Measurements}

At 21 and 35 days of age, after fasting overnight, birds were individually weighed, and feed intake (FI) was recorded per replicate. Body weight gain (BWG) and feed conversion ratio (FCR) were calculated.

\section{Carcass and Tibia Bone Parameters}

At the end of the experiment, after fasting overnight, two birds close to average weight of each replicate were selected and slaughtered for determination of carcass characteristics. Weight of carcass, breast meat, thigh, drumstick, wing, liver, heart, and gizzard were recorded and calculated as percent of live body weight. Weights of immune related organs (thymus, spleen, and bursa of Fabricius) were taken and expressed as percent of live body weight.

Right and left tibia from the slaughtered birds was taken, cleaned of soft tissue and fat-extracted in petroleum ether in a sealed glass container for 72 hours. Tibia was dried at $105^{\circ} \mathrm{C}$ for 3 hours, weighed and length was measured with a caliper and weight/length index were calculated. Relative bone density was calculated using the following formula: Relative bone density = bone weight/ live body weight $\mathrm{x} 100$, as described by Charuta et al. (2013). Robusticity index: was calculated using the following formula: Robusticity index = tibia bone length/cube root of tibia bone weight. The robusticity index was proposed by Riesenfeld (1972) and the bone weight/bone length index was used by Seedor et al. 1991 . Robusticity index has been shown to be correlated with bone mineral content and a smaller robusticity index indicates stronger bones (Monteagudo et al. 1997). Then, the tibia was ashed at $600^{\circ} \mathrm{C}$ for $4 \mathrm{~h}$. The content of tibia ash of $\mathrm{Ca}, \mathrm{P}, \mathrm{Zn}$, and $\mathrm{Mn}$ were determined based on the official methods of analysis (AOAC 1995). Tibia ash and minerals were expressed as a percentage of the fat-free dry weight.

\section{Ileum, Liver and Tibia Bone Histo-morphological Analysis}

Ileum samples, approximately $10 \mathrm{~cm}$ from the lower end of the duodenal loop, were carefully dissected during the slaughter time, rinsed with saline $(0.9 \% \mathrm{NaCl})$ and fixed in $12 \%$ formalin solution. Representative samples of liver were carefully dissected during the slaughtered time and immediately fixed in adequate volume of $10 \%$ formalin solution. After dehydration and embedding in paraffin wax, thin transverse sections $(4-5 \mu \mathrm{m})$ for different organs were stained with the ordinary hematoxylin and eosin stain (H\&E) according to Bancroft and Stevens (1990). Histological sections were examined using a light microscope provided with a digital camera under magnification power $\times 40$. Stereological image software (Image J 1.50b) was used to estimate the crypt depth and villi height from ileum images, and its scale was calibrated to the micrometer unit $(\mu \mathrm{m})$. From the villus tip to the villus-crypt junction, the villus height was measured (3-5 villi per sample). The depth of the crypt was measured from the base of the villus to the submucosa. For each segment, the villus:crypt ratio was computed. From the epimysium to the submucosa layer, the muscular layer thickness (Musculosa depth) was the smallest vertical distance.

Histological examinations for bone were made on middle part of the tibia diaphysis specimens taken from three sampled broilers in each group at 35 days of age. Then fixation in $10 \%$ formalin solution and decalcification with $5 \%$ formic acid were done. All sections were dehydrated in ascending grades of ethyl alcohol, cleared in xylol and embedded in paraffin wax according to previous studies (Junqueira et al. 1971; Al-Hussaini and Demian 1974; Abd El-Hamid 1981). Histological sections were examined using light microscope provided with a digital camera under low magnification power $\times 10$. The histological technique was conducted at the Pathology Laboratory, National Cancer Institute, Cairo Univ., Egypt. 


\section{Statistical Analysis}

Data were statistically analyzed for analysis of variance using the General Linear Model of the Statistical Analysis System (SAS 1994). Significant differences among treatment means were separated by Duncan's new multiple range test (Duncan 1955) with a 5\% level of probability.

\section{RESULTS}

\section{Growth Performance}

Growth performance (BWG, FI and FCR) of broiler chicks fed diets supplemented with ITM or/and OTM are shown in Table 3. Using OTM alone in broiler diets (T2) or with ITM (T3) resulted in significant improvement in FCR $(\mathrm{P}<0.05)$ compared to those fed ITM alone $(\mathrm{T} 1)$. Meanwhile, these dietary treatments (T1, T2 and T3) did not significantly affect BWG and FI at different ages (21 and 35 days of age). No significant differences were observed in growth performance between T2 and T3. At 35 days of age, higher BWG was observed in broilers fed OTM containing diets (T2 and T3) being 2006g compared to $1976 \mathrm{~g}$ for birds fed ITM alone (T1), with no significant differences.

\section{Carcass Characteristics}

Carcass characteristics of broilers fed the different dietary treatments are shown in Table 4. Dietary treatments did not significantly affect dressing percentage. Also, there were no significant differences related to dietary treatments on carcass parts ( $\%$ of live body weight): breast meat, drumsticks, thigh, wing and back+neck. Feeding OTM, ITM or both together had no significant effect on liver, gizzard, and heart. Weight of related immune organs (bursa, thymus and spleen) as a percentage of live body weight were slightly $(\mathrm{P}>0.05)$ improved with OTM supplementation without significant differences among treatments.

\section{Tibia Bone Parameters}

Tibia bone parameters of broilers fed the different dietary treatments are shown in Table 5. Tibia weight, tibia length, weight/length index, relative bone density (tibia weight/LBW X 100) and robusticity index (tibia length/cube root of tibia weight) showed no significant differences among the dietary treatments. Tibia ash percentage was significantly $\quad(\mathrm{P}<0.01) \quad$ improved with OTM supplementation. However, the highest value of tibia ash \% was recorded for birds fed OTM (T2) being $48.84 \%$ followed by those fed on OTM + ITM (T3) being $46.47 \%$ and the lowest value was recorded for those fed ITM (T1) being $44.72 \%$. Tibia calcium, phosphorus, zinc and manganese $\%$ varied non-significantly $(\mathrm{P}>0.05)$ between the treated groups. Relative bone density and robusticity index that indicate bone strength showed no significant effect.

\section{Ileum, Liver and Tibia Bone Histo-morphological Analysis}

The microarchitecture of ileum from broilers of the different experimental groups are shown in Fig. 1. Histomorphological analysis of the villus height, crypt depth, villus/crypt ratio and musculosa depth of the experimental groups are presented in Table 6. Histo-morphological
Table 1: Formulation and nutrient composition of the experimental diets

\begin{tabular}{|c|c|c|}
\hline Ingredients $\%$ & Starter & Grower \\
\hline Yellow corn & 58.15 & 61.49 \\
\hline Soybean meal (48\%) & 37.00 & 31.00 \\
\hline Soybean oil & 0.80 & 3.50 \\
\hline Dicalcium phosphate & 1.60 & 1.50 \\
\hline Limestone & 1.20 & 1.30 \\
\hline Vitamin premix ${ }^{(1)}$ & 0.15 & 0.15 \\
\hline $\mathrm{NaCl}$ & 0.25 & 0.25 \\
\hline L-lysine $\mathrm{HCl}$ & 0.16 & 0.15 \\
\hline DL-methionine & 0.26 & 0.25 \\
\hline Threonine & 0.10 & 0.10 \\
\hline Choline chloride & 0.12 & 0.10 \\
\hline Na-Bicarbonate & 0.15 & 0.15 \\
\hline Anticoccidial & 0.06 & 0.06 \\
\hline Total & 100 & 100 \\
\hline \multicolumn{3}{|l|}{ Calculated Composition $^{(\dagger)}$} \\
\hline Crude Protein $\%$ & 22.76 & 20.00 \\
\hline $\mathrm{ME}(\mathrm{kcal} / \mathrm{kg})$ & 2920 & 3140 \\
\hline Lysine $\%$ & 1.42 & 1.28 \\
\hline Methionine $\%$ & 0.65 & 0.53 \\
\hline Methionine+Cystine \% & 0.99 & 0.88 \\
\hline Calcium \% & 0.95 & 0.93 \\
\hline Non Phytate P \% & 0.50 & 0.40 \\
\hline
\end{tabular}

(1) Vitamin premix supplied/kg of diet: Vit A 12000IU; Vit $\mathrm{D}_{3}$ 2200IU; Vit E 10mg; Vit $K_{3} 2 \mathrm{mg}$; Vit $\mathrm{B}_{1} 1 \mathrm{mg}$; Vit $\mathrm{B}_{2} 4 \mathrm{mg}$; Vit $\mathrm{B}_{6} 1.5 \mathrm{mg}$; Vit $\mathrm{B}_{12}$, 10mg; Niacin 20mg; Pantothenic acid 10mg; Folic acid 1mg; Biotin 50mg; ${ }^{(\dagger)}$ According to NRC (1994).

Table 2: Levels of inorganic and organic trace minerals used in the experimental diets

\begin{tabular}{llll}
\hline Ingredients $(\mathrm{g} /$ ton$)$ & $\mathrm{T} 1$ & $\mathrm{~T} 2$ & $\mathrm{~T} 3$ \\
\hline ITM premix $^{(1)}$ & 1500 & --- & 750 \\
OTM premix $^{(2)}$ & --- & 500 & 250 \\
\hline
\end{tabular}

(1) Inorganic trace mineral premix used at $1500 \mathrm{~g} /$ ton supplied/kg of diet: Zinc $80 \mathrm{mg}$, Manganese 100mg, Copper $8 \mathrm{mg}$, Iron $80 \mathrm{mg}$, Selenium $0.15 \mathrm{mg}$, cobalt 0.50 , molybdenum $1 \mathrm{mg}$ and Iodine 1mg: Organic trace mineral premix used at $500 \mathrm{~g} / \mathrm{ton}$ supplied/kg of diet: Zinc 15mg, Manganese 30mg, Copper 5mg, Iron $5 \mathrm{mg}$ and Selenium $0.20 \mathrm{mg}$.

Table 3: Growth performance of broilers fed the different dietary treatments

\begin{tabular}{|c|c|c|c|c|c|}
\hline \multirow{2}{*}{$\begin{array}{l}\text { Days/ } \\
\text { Parameters }\end{array}$} & \multicolumn{3}{|c|}{ Dietary treatments } & \multirow[t]{2}{*}{ SEM } & \multirow{2}{*}{$\begin{array}{l}\text { Signi- } \\
\text { ficant }\end{array}$} \\
\hline & $\mathrm{T} 1$ & $\mathrm{~T} 2$ & $\mathrm{~T} 3$ & & \\
\hline \multicolumn{6}{|c|}{ From $1-22$ days } \\
\hline A & 1023 & 1042 & 1026 & 5.86 & NS \\
\hline B & 1408 & 1404 & 1391 & 8.07 & NS \\
\hline $\mathrm{C}$ & $1.38^{\mathrm{a}}$ & $1.35^{\mathrm{b}}$ & $1.36^{\mathrm{b}}$ & 0.01 & * \\
\hline \multicolumn{6}{|c|}{ From $22-35$ days } \\
\hline A & 1094 & 1102 & 1118 & 11.69 & NS \\
\hline B & 1532 & 1503 & 1524 & 12.32 & NS \\
\hline $\mathrm{C}$ & $1.40^{\mathrm{a}}$ & $1.36^{\mathrm{b}}$ & $1.36^{\mathrm{b}}$ & 0.01 & * \\
\hline \multicolumn{6}{|c|}{ From $1-35$ days } \\
\hline A & 1976 & 2006 & 2006 & 13.06 & NS \\
\hline B & 2940 & 2906 & 2915 & 16.43 & NS \\
\hline $\mathrm{C}$ & $1.49^{\mathrm{a}}$ & $1.45^{\mathrm{b}}$ & $1.45^{\mathrm{b}}$ & 0.01 & $*$ \\
\hline
\end{tabular}

$\mathrm{A}=$ Body weight gain $(\mathrm{g}) ; \mathrm{B}=$ Feed intake $(\mathrm{g}) ; \mathrm{C}=\mathrm{FCR}(\mathrm{g} / \mathrm{g})$. T1: $100 \%$ inorganic minerals; T2: $100 \%$ organic minerals; T3: $50 \%$ inorganic minerals $+50 \%$ organic minerals: SEM: Standard error of means; *: significant at $5 \%$ probability $(\mathrm{P}<0.05)$. Ns: not significant at $5 \%$.

analysis of ileum revealed that, broiler chicks fed diets with organic minerals showed significant decrease $(\mathrm{P}<0.05)$ in the length of villi $(\mu \mathrm{m})$ compared to the control group (T1). Also, T1 group has the highest villi length compared to the other groups. On other hands, crypt depth $(\mu \mathrm{m})$ was 
Table 4: Carcass characteristics and organs weight (\% of live body weight) of broilers fed the different dietary treatments at 35 days of age

\begin{tabular}{llllll}
\hline Item & \multicolumn{3}{c}{ Dietary treatments } & SEM & Significan \\
\cline { 2 - 4 } & T1 & T2 & T3 & & t \\
\hline Dressing & 73.86 & 73.80 & 73.41 & 0.22 & NS \\
Breast & 31.98 & 31.39 & 31.16 & 0.15 & NS \\
Drumsticks & 9.49 & 9.71 & 9.64 & 0.10 & NS \\
Thigh & 12.83 & 12.61 & 13.28 & 0.16 & NS \\
Wings & 7.29 & 7.47 & 7.22 & 0.07 & NS \\
Back and neck & 12.28 & 12.06 & 12.32 & 0.15 & NS \\
Liver & 1.938 & 2.109 & 2.089 & 0.04 & NS \\
Heart & 0.524 & 0.517 & 0.522 & 0.01 & NS \\
Gizzard & 1.481 & 1.545 & 1.517 & 0.04 & NS \\
Bursa & 0.071 & 0.100 & 0.085 & 0.01 & NS \\
Spleen & 0.115 & 0.118 & 0.119 & 0.01 & NS \\
Thymus & 0.214 & 0.227 & 0.229 & 0.01 & NS
\end{tabular}

T1: $100 \%$ inorganic minerals; T2: $100 \%$ organic minerals; T3: $50 \%$ inorganic minerals $+50 \%$ organic minerals: SEM: Standard error of means; Ns: not significant at $5 \%$.

Table 5: Tibia bone parameters of broilers fed the different dietary treatments at 35 days of age

\begin{tabular}{llllll}
\hline Item & \multicolumn{3}{c}{ Dietary treatments } & \multicolumn{2}{c}{ SEM Significant } \\
\cline { 2 - 4 } & $\mathrm{T} 1$ & $\mathrm{~T} 2$ & $\mathrm{~T} 3$ & & \\
\hline Weight $(\mathrm{g})$ & 5.43 & 5.36 & 5.75 & 0.13 & $\mathrm{NS}$ \\
Length $(\mathrm{mm})$ & 86.45 & 86.25 & 86.49 & 0.53 & $\mathrm{NS}$ \\
Weight/length index & 0.063 & 0.062 & 0.066 & 0.01 & $\mathrm{NS}$ \\
Relative bone density & 0.240 & 0.241 & 0.250 & 0.01 & $\mathrm{NS}$ \\
Robusticity index & 49.19 & 49.28 & 48.36 & 0.22 & $\mathrm{NS}$ \\
Ash\% & $44.72^{\mathrm{c}}$ & $48.84^{\mathrm{a}}$ & $46.47^{\mathrm{b}}$ & 0.54 & $*$ \\
$\mathrm{Ca} \%$ & 26.11 & 27.09 & 26.55 & 0.40 & $\mathrm{NS}$ \\
$\mathrm{P} \%$ & 17.23 & 17.66 & 17.67 & 0.35 & $\mathrm{NS}$ \\
Zn (mg/kg) & 320 & 300 & 305 & 3.22 & $\mathrm{NS}$ \\
$\mathrm{Mn}(\mathrm{mg} / \mathrm{kg})$ & 5.56 & 5.75 & 5.95 & 0.17 & $\mathrm{NS}$ \\
\hline
\end{tabular}

T1: $100 \%$ inorganic minerals; T2: $100 \%$ organic minerals; T3: $50 \%$ inorganic minerals $+50 \%$ organic minerals. SEM: Standard error of means; *: significant at $5 \%$ probability $(\mathrm{P}<0.05)$. Ns: not significant at $5 \%$.

Table 6: Effect of different treatments on ileum histomorphology measurements of broilers at 35 days of age

\begin{tabular}{llllll}
\hline Items & \multicolumn{3}{c}{ Experimental groups } & SEM & Significant \\
\cline { 2 - 5 } & T1 & T2 & T3 & & \\
\hline Villus height $(\mu \mathrm{m})$ & $395^{\mathrm{a}}$ & $377^{\mathrm{b}}$ & $365^{\mathrm{b}}$ & 19.51 & $*$ \\
Crypt depth $(\mu \mathrm{m})$ & $83.8^{\mathrm{a}}$ & $60.8^{\mathrm{b}}$ & $57.3^{\mathrm{b}}$ & 5.30 & $*$ \\
Villus: crypt ratio & $4.71^{\mathrm{b}}$ & $6.20^{\mathrm{a}}$ & $6.37^{\mathrm{a}}$ & 0.61 & $*$ \\
Musculosa depth $(\mu \mathrm{m})$ & $104^{\mathrm{a}}$ & $78^{\mathrm{b}}$ & $75^{\mathrm{b}}$ & 5.01 & $*$
\end{tabular}

T1: $100 \%$ inorganic minerals; T2: $100 \%$ organic minerals; T3: $50 \%$ inorganic minerals $+50 \%$ organic minerals. SEM: Standard error of means; *: significant at $5 \%$ probability $(\mathrm{P}<0.05)$.

decreased significantly $(\mathrm{P}<0.05)$ in $\mathrm{T} 2$ and $\mathrm{T} 3$ groups compared with the control one. Villus height: crypt depth ratio was significantly $(\mathrm{P}<0.05)$ increased in birds fed organic minerals (T2 and T3). Musculosa depth showed a significant decrease $(\mathrm{P}<0.05)$ in muscular layer thickness of the ileum of groups fed organic minerals.

Histological examination of liver sections is shown in Fig. 2 (Plate 1-3). Liver sections showed normal hepatic parenchyma structure. Polyhedral and angular shaped hepatocytes surrounding the central vein extended to the periphery of the hepatic lobules, blood sinusoid with thick walls could be seen surrounded with many lymphocytes and apparent lacunae in between hepatic cells. Also, several homogeneous masses of hepatic cords and intralobular blood vessels could be seen (Plate 1).
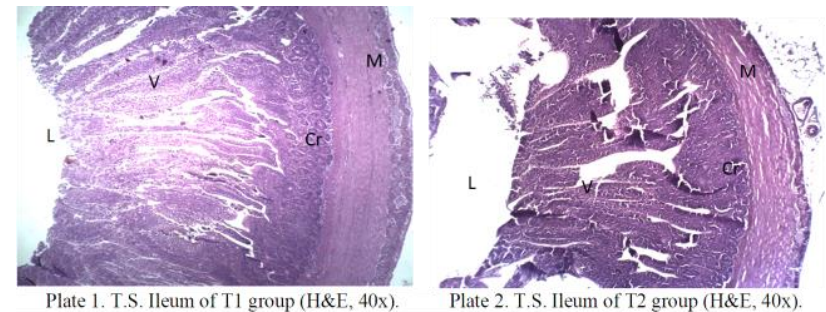

Plate 1. T.S. Ileum of $\mathrm{T} 1$ group (H\&E, 40x).

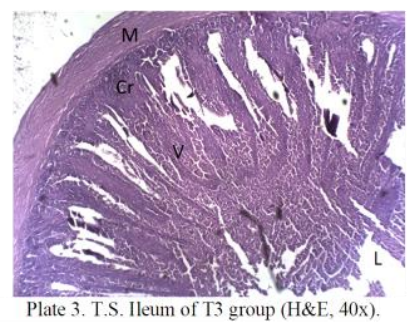

Fig. 1: Cross section through ileum from broilers chicks of different experimental groups at 35DOA. ( $\mathrm{H} \& \mathrm{E} \times 40)$, $\mathrm{M}$ muscularis mucosa; Cr: crypts of Lieberkühn; V: Villi; L: lumen.

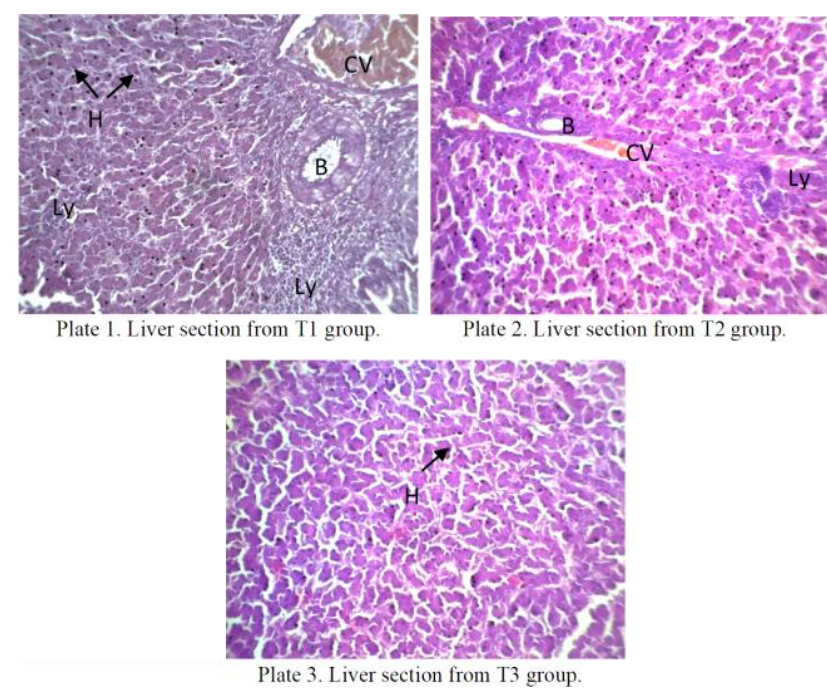

Fig. 2: Transfer section of broilers livers from different experimental groups at 35 days of age $(H \& E, 40 x)$. B: Bile duct, H: Hepatocytes, CV: Central Vein, LY: Lymphocytic cells.

The liver tissue in T2 and T3 (Plates 2 and 3) was healthy and normal, where the hepatic cell masses were well arranged, and no fluids present in between cords. The hepatic cords were very well arranged in two-cells cords and dark-stained hepatocytes with few necrotic areas. However, histological findings in all experimental groups revealed that the present levels of inorganic, organic trace minerals or their combination in broilers diet were safe and had no toxic effects in hepatic tissues.

The histological structure of the tibia bone of 35-days chicks as influenced by different treatments are shown in Fig. 3 (plates 1-3). It appears that, tibia bone sections of all groups are nearly similar in structure and can observe a greater area of compact bone and then the smaller area of proliferative zone in which the spongy bones tended to be well developed. There are many osteocytes and haversian canals between the lacunae, in the bone matrix. Plate 1 (T1 group) shows the tibia section of $\mathrm{T} 1$ where the bone was enclosed by the periosteum $(\mathrm{P})$. The cortical bone (CB) layer was thick and many true well-arranged osteocytes that fully enclosed within lacunae (L) were observed. 


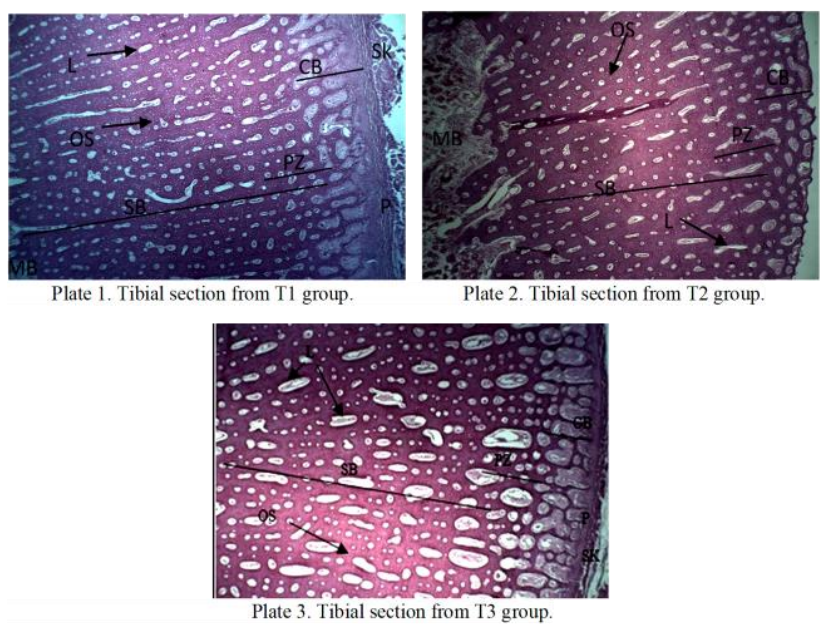

Fig. 3: Transfer sections of broilers tibia from different experimental groups at 35 DOA (H\&E, 10x). P: Periosteum, CB: Cortical bone, SB: Spongy bone, MB: Medullary bone, PZ: Proliferative zone, OS: Osteoblasts, L: Lacunae, SK: Skeletal muscles.

Also, a large spongy bone (SB) layer could be seen that filled with many oval-shaped osteoblasts. These cells were abundant in the proliferative zone (PZ) where a new bone (CB) will be formed. The medullary bone (MB) cavity is present that filled with epithelial cells and/or endothelial cells being immature RBCs. Also, the natural state of bone formation could be observed in plate 2 (T2 group). The number and size of lacunae were diminished, while osteocytes (bone-forming cells) were abundant and the area of calcified bone is greatly increased, which be an indicator of progressively osteogenic process. However, plate 3 (T3 group) showed important changes including increases of long irregular-shaped lacunae and the osteoblasts. Also, there are many osteoids (dark-stained cells) that appear to be fully enclosed within the lacunae, which reflect the incoming new and rapid bone formation.

\section{DISCUSSION}

\section{Growth Performance}

The obtained results of using OTM are in agreement with previous studies. Bao et al. (2007) reported that there was no significant difference $(\mathrm{P}>0.05)$ in live body weight between OTM and ITM supplementation to broiler diets. Leeson and Caston (2008) reported that although OTM facilitated greater bioavailability, they did not significantly affect BWG of birds. The observed improvement in FCR could be attributed to organic minerals which has a high bioavailability and remains long time in the gut compared with inorganic minerals, consequently, improves the feed utilization as reported by Nollet et al. (2007) and Leeson and Caston (2008). Rajkumar et al. (2018) showed that final body weight did not differ significantly between birds fed OTM and ITM. Some researchers reported that organic and inorganic $\mathrm{Zn}$ had no significant effect on the body weight (Salim et al. 2012; Sunder et al. 2013; Zakaria et al. 2017; Pacheco et al. 2017). However, Ao et al. (2006) found that using organic zinc in broiler diets improved live body weight and feed efficiency. M'Sadeq et al. (2018) reported no significant differences $(\mathrm{P}>0.05)$ in $\mathrm{FI}, \mathrm{BWG}$ and FCR with 375 and $500 \mathrm{~g} /$ ton organic yeast proteinate trace mineral premix and with $750 \mathrm{~g} /$ ton inorganic trace mineral premix supplementation to broiler diets at 25 days of age, while at day 39 of age, BWG and FCR were significantly improved $(\mathrm{P}<0.01)$ with organic trace minerals supplementation compared with inorganic mineral treatment. These results were in good agreement with those obtained in the present study. Khatun et al. (2019) showed that birds fed two forms of OTM, propionate and proteinate had better performance in comparison with those receiving ITM of commercial broilers. Abuajamieh et al. (2020) reported that addition of organic zinc had little or no effects on the performance parameters measured in broiler chicks.

The results of feed intake (FI) revealed that, chicks fed OTM supplemented diets consumed less amounts of feed up to five weeks of age and so, the differences were not significant $(\mathrm{P}>0.05)$ compared with the ITM fed group. These results are in agreement with those obtained by previous studies (Sunder et al. 2013; Baloch et al. 2017). Anil et al. (2012) reported that supplementation of $\mathrm{Zn}$ at levels of 20, 40, 60 and $80 \mathrm{mg} / \mathrm{kg}$ diet, whether in inorganic or organic form, did not affect FI of broilers. However, ELHusseiny et al. (2012) reported that OTM reduced feed intake compared with ITM.

\section{Carcass Characteristics}

These findings agreed with those of Lu et al. (2006), who stated that relative weights of liver, heart, or spleen did not affect as a result of adding organic Mn to a broilers diet. Also, Zhao et al. (2010) found that OTM had no significant effects on dressing percentage and giblet weights. The OTM had no significant effects on liver, gizzard and giblet weights which agreed with the results of previous studies (Bao et al. 2007; Rossi et al. 2007; Bao and Choct 2009; Zhao et al. 2010). Also, Mishra et al. (2013) reported that live weight, dressed weight, eviscerated weight, drumstick, thigh, back, neck, breast and wing yield of broiler chicks did not differ significantly $(\mathrm{P}>0.05)$ with supplementation of organic mineral $(\mathrm{Zn}, \mathrm{Cu}$ and $\mathrm{Mn}$ ).

M'Sadeq et al. (2018) reported that inorganic and organic trace mineral supplementation had no effect $(\mathrm{P}>0.05)$ on relative weights of thymus, bursa of Fabricius and carcass composition of broilers at day 39 of age. Khatun et al. (2019) reported that broiler chicks fed two forms of OTM, propionate and proteinate produced more wing, breast and drumstick meat yield as compared with those received the ITM.

\section{Tibia Bone Parameters}

The lower robusticity index indicates that bone structure is stronger and healthier (Riesenfeld 1972; Yalcin et al. 2001). The obtained results are in agreement with the previous reports of Abdallah et al. (2009); Zhao et al (2010) and Britanico et al. (2012). Organic trace minerals added to broilers' diet at levels of 50 and $100 \%$ did not affect tibia bone measurements (Abdallah et al. 2009). Also, M'Sadeq et al. (2018) reported no significant differences, in bone quality, were observed on broiler fed diets with organic and inorganic trace mineral supplementation at day 39 of age $(\mathrm{P}>0.05)$. In contrast, the supplementation of the organic form of zinc, copper and manganese has improved the tibia weight and tibia length 
of broiler chickens (EL-Husseiny et al. 2012). Moreover, organic trace minerals supplementation enhanced the biochemical characteristics of bone (Ferket et al. 2009). Slightly higher value of relative bone density with the organic trace mineral supplementation may imply that these birds had a better bone mineralization.

\section{Ileum, Liver \& Tibia Bone Histo-morphological Analysis}

All ileum sections showed the main ileal layers, muscularis mucosa layer, submucosa, mucosa, crypts of Lieberkühn and villi as described by William and Linda 2000. Villus height and the ratio of villus height to crypt depth are indicators of gastrointestinal tract morphology and intestine transfers nutrients required for growth, maintenance and production in animals. Absorption of nutrients by intestine depends upon the surface area provided by the villi lining intestinal tract (Shamoto and Yamauchi 2000). Histologically, high ability of absorption of nutrients could be achieved if long villi is existing due to the increase in surface area (Caspary 1992). The present observations showed low villus height associated with better growth performance in broilers received organic minerals (T2 and T3 groups). These improvements in growth performance especially in FCR may be referred to the increase in villus height: crypt depth ratio. In this regard, Parsaie et al. (2007) and Echeverry et al. (2016) mentioned that villus height: crypt depth ratio has normally been associated with better harmony between cellular turnovers. Trace minerals may influence the development of the intestinal structure of broiler chickens (Sun et al. 2005). The present findings are in agreement with Abuajamieh et al. (2020) who stated that dietary trace minerals in organic form improved the morphological characteristics of the intestines of broiler chickens. Moreover, it may have a role in maximization of intestinal efficiency in nutrient absorption under thermoneutral or heat stress conditions.

The positive effects of OTM or ITM on liver health may be due to the roles of these trace minerals in antioxidant defense systems and prevent oxidative stress which lead to cell damage. In this context, Ma et al. (2011) showed that high dietary levels of organic zinc improved the activity of superoxide dismutase and glutathione peroxidase enzymes, as well as lowering the malondialdehyde content in chickens' livers. Also, Bun et al. (2011) reported that organic $\mathrm{Zn}$ supplementation reduced oxidative stress. Similarly, Attia et al. (2010) reported that the Gimmizah strain chickens fed the organic form of Se (seleno-methionine) showed fewer toxic effects in hepatic tissues than those receiving the inorganic form.

Considering tibia bone, findings from the present histological sections revealed that levels used in our study of inorganic, organic trace minerals or their combination in broilers diet maintained normal osteogenesis process without major differences or adverse effect on broilers tibia structure at 35 days of age. Similar studies of Favero et al. (2013a and 2013b) based on different microelements used in combination, indicated that the addition of organic zinc, copper and manganese to Cobb 500 breeder hen diets significantly improved eggshell weight and thickness and improved bone mineralization parameters, i.e. tibia calcification and thickness. On the other hand, Tomaszewska et al. (2017) found that zinc dietary supplementation of up to $50 \mathrm{mg} / \mathrm{kg}$ diet, whether in organic or inorganic form, improved mechanical properties of the femur bone and indicated osteoporotic effects on trabecular bone where histomorphometry displayed significant changes in spongy bone than in cortical bone. In a study by Yildiz et al. (2011) on laying hens, indicated that dietary organic manganese supplementation performed better than inorganic manganese, in terms of effects on the percentage of unbroken eggs and tibia bone quality indices. These beneficial effects were probably due to the changes in the mineral element distribution in the hens and to manganese accumulation in bones, promoted using organic forms of manganese.

\section{Conclusion}

The effects of supplementing low organic trace minerals premix to broilers diets on growth performance and tibia bone parameters were similar or better than the inorganic form. From these results, it could be concluded that organic trace minerals can be included at lower levels in broilers diet than the current recommended levels for inorganic trace minerals, without any negative effects on growth performance. Additionally, using lower levels of organic trace minerals replacing inorganic sources in broiler diets may have benefits in feed conversion ratio and histological analysis of ileum liver and tibia bone. Thus, organic trace minerals improve absorption characteristics and provide bird's requirements. Furthermore, using low mineral levels in feeding broilers led to less excretion and share in avoiding or decreasing environmental pollution. Future studies on dietary organic trace minerals supplementation will help in understanding the absorption mechanisms and their effects on performance, carcass meat and bone quality.

\section{Author's Contribution}

All authors contributed equally to study design methodology, interpretation of results, and writing of the manuscript.

\section{REFERENCES}

Abd El-Hamid Z, 1981. Histology: Part I. Dar El Shaab for Press, Cairo, Egypt, pp: I-XI and pp:113-118.

Abdallah AG, El-Husseiny OM and Abdel-Latif KO, 2009. Influence of some dietary organic minerals supplementation on broilers performance. International Journal of Poultry Science 8: 291-298. https://dx.doi.org/10.3923/ijps.2009. $\underline{291.298}$

Abuajamieh M, Abdelqader A, Irshaid R, Hayajneh F, AlKhaza'leh JM and Al-Fataftah AR, 2020. Effects of organic zinc on the performance and gut integrity of broilers under heat stress conditions. Archives Animal Breeding 63: 125135. https://dx.doi.org/10.5194\%2Faab-63-125-2020

Al-Hussaini AH and Demian ES, 1974. Practical Animal Biology. Vol. 1. The Toad. $3^{\text {rd }}$ Ed. Dar El-Maarf, Cairo, Egypt; pp: 280-290.

Alagawany M, Elnesr SS, Farag MR, Tiwari R, Yatoo MI, Karthik K, Michalak I and Dhama K, 2021. Nutritional significance of amino acids, vitamins and minerals as nutraceuticals in poultry production and health - A comprehensive review. Veterinary Quarterly 41: 1-29. https://doi.org/10.1080/01652176.2020.1857887

Anil KC, Ramana JV, Rama PJ, Sudheer SD and Satyanarayana RPVV, 2012. Influence of zinc sulphate and zinc-methionine 
dietary supplementation on carcass characteristics and feed efficiency of broilers. Annals of Biological Research 3: 4215-4221.

Ao T, Pierce JI, Power R, Dawson KA, Pescator AJ, Cantor AH and Ford MJ, 2006. Evaluation of bioplex $\mathrm{Zn}$ as organic zinc source for chicks. International Journal of Poultry Science 5: 808-811. https://dx.doi.org/10.3923/ijps.2006.808.811

AOAC, 1995. Official Methods of Analysis. $16^{\text {th }} \mathrm{Ed}$, Association of Official Analytical Chemists, Washington DC, USA.

Arif M, Hussain I, Mahmood MA, Abd El-Hack ME, Swelum AA, Alagawany M and Komany A, 2019. Effect of varying levels of chromium propionate on growth performance and blood biochemistry of broilers. Animals (Basel) 9: 935. https://doi.org/10.3390/ani9110935

Attia YA, Abdalah AA, Zeweil HS, Bovera F, El-Din AT and Araft MA, 2010. Effect of inorganic or organic selenium supplementation on productive performance, egg quality and some physiological traits of dual-purpose breeding hens. Czech Journal of Animal Science 55: 505-519. https://doi.org/10.17221/1715-CJAS

Baloch Z, Yasmeen N, Pash TN, Ahmad A, Taj MK, Khosa AN, Marghazani IB, Bangulzai N, Ahmad I and Hua YS, 2017. Effect of replacing inorganic with organic trace minerals on growth performance, carcass characteristics and chemical composition of broiler thigh meat. African Journal of Agricultural Research 12: 1570-1575.

Bancroft JD and Stevens A, 1990. Theory and Practice of Histological Technique. $3^{\text {rd }}$ Ed. Churchill Livingstone, Edinburgh, UK.

Bao YM, Choct M, Iji PA and Bruerton K, 2007. Effect of organically complexed copper, iron, manganese, and zinc on broiler performance, mineral excretion, and accumulation in tissues. Journal of Applied Poultry Research 16: 448-455. https://doi.org/10.1093/japr/16.3.448

Bao YM and Choct M, 2009. Trace minerals nutrition for broiler chickens and prospects of application of organically complexed trace minerals: a review. Animal Production Science 49: 269-282. http://dx.doi.org/10.1071/EA08204

Bortoluzzi C, Vieira BS and Applegate TJ, 2020. Influence of dietary zinc, copper, and manganese on the intestinal health of broilers under Eimeria challenge. Frontiers in Veterinary Science 7: 13. https://doi.org/10.3389/fvets.2020.00013

Britanico EB, Merca FE, Angeles AA, Acda SP and Luis ES, 2012. Effects of supplementing diets with amino acid chelates of copper, zinc, manganese and iron on the performance of broilers. Philippines Journal of Veterinary and Animal Sciences 38: 1-10.

Bun SD, Guo YM, Guo FC, Ji FJ and Cao H, 2011. Influence of organic zinc supplementation on the antioxidant status and immune responses of broilers challenged with Eimeria tenella. Poultry Science 90: 1220-1226. https://doi.org/ 10.3382/ps.2010-01308

Burrell AL, Dozier WA, Davis AJ, Compton MM, Freeman ME, Vendrell PF and Ward TL, 2004. Responses of broilers to dietary zinc concentrations and sources in relation to environmental implications. British Poultry Science 45: 225263. https://doi.org/10.1080/00071660410001715867

Carvalho L, Limão V, Fagundes NS and Fernandes E, 2018. Excretion level of trace minerals in broilers fed organic mineral. Ciência Animal Brasileira 19: 1-8. https://doi.org/10.1590/1809-6891v19e-33086

Caspary WF, 1992. Physiology and pathophysiology of intestinal absorption. The American Journal of Clinical Nutrition 55: 299S-308S. https://doi.org/10.1093/ajcn/55.1.299s

Charuta A, Dzierzęcka M, Komosa M, Biesiada-Drzazga B, Działa-Szczepańczyk E and Cooper RG, 2013. Age- and sex-related changes in mineral density and mineral content of the tibiotarsal bone in quails during post-hatching development. Kafkas Üniversitesi Veteriner Fakültesi Dergisi 19: 31-36. http://dx.doi.org/10.9775/kvfd.2012.7055
Dieck HT, Doring F, Roth HP and Daniel H, 2003. Changes in rat hepatic gene expression in response to zinc deficiency as assessed by DNA arrays. The Journal of Nutrition 133: 1004 1010. https://doi.org/10.1093/jn/133.4.1004

Duncan DB, 1955. Multiple Rang and Multiple F-Test. Biometrics 11: 1-42.

Echeverry H, Yitbarek A, Munyaka P, Alizadeh M, Cleaver A, Camelo-Jaimes G and Rodriguez-Lecompte JC, 2016. Organic trace mineral supplementation enhances local and systemic innate immune responses and modulates oxidative stress in broiler chickens. Poultry Science 95: 518-527. https://doi.org/10.3382/ps/pev374

El-Husseiny OM, Hashish SM, Ali RA, Arafa SA, Abd EL-Samee LD and Olemy AA, 2012. Effects of feeding organic zinc, manganese and copper on broiler growth, carcass characteristics, bone quality and mineral content in bone, liver and excreta. International Journal of Poultry Science 11: 368-377. http://dx.doi.org/10.3923/ijps.2012.368.377

Favero A, Vieira SL, Angel CR, Bess F, Cemin HS and Ward TL, 2013a. Reproductive performance of Cobb 500 breeder hens fed diets supplemented with zinc, manganese, and copper from inorganic and amino acid-complexed sources. Journal of Applied Poultry Research 22: 80-91. https://doi.org/ 10.3382/japr.2012-00607

Favero A, Vieira SL, Angel CR, Bos-Mikich A, Lothhammer N, Taschetto D, Cruz RFA and Ward TL, 2013b. Development of bone in chick embryos from Cobb 500 breeder hens fed diets supplemented with zinc, manganese, and copper from inorganic and amino acid-complexed sources. Poultry Science 92: 402-411. https://doi.org/10.3382/ps.2012-02670

Ferket PR, Oviedo-Rondon EO, Mente PL, Bohorquez DV, Santos AA, Grimes JL, Richards JD, Dibner JJ and Felts V, 2009. Organic trace minerals and 25-hydroxycholecalciferol affect performance characteristics, leg abnormalities, and biomechanical properties of leg bones of turkeys. Poultry Science 88: 118-131. https://doi.org/10.3382/ps.2008-00200

Figueiredo Júnior JP, Costa FGP, Givisiez PEN, Lima MR, Silva JHV, Figueiredo-Lima DF, Saraiva EP and Santana MHM, 2013. Substitution of inorganic minerals for organic minerals in the diet of semi heavy layers. Brazilian Journal of Veterinary and Animal Sciences 65: 513-518. https://doi.org/10.1590/S0102-09352013000200030

Ghasemi HA, Hajkhodadadi I, Hafizi M, Taherpour K and Nazaran MH, 2020. Effect of advanced chelate technology based trace minerals on growth performance, mineral digestibility, tibia characteristics, and antioxidant status in broiler chickens. Nutrition \& Metabolism (Lond) 17: 94. https://doi.org/10.1186/s12986-020-00520-5

Junqueira IC, Carnerior J and Long JA, 1971. Basic Histology. Chapter $1,5^{\text {th }}$ Ed, Koogan SAG (ed), Rio de Janerio, Brazil.

Khatun A, Das Chowdhury S, Roy BC, Dey B, Haque A and Chandran B, 2019. Comparative effects of inorganic and three forms of organic trace minerals on growth performance, carcass traits, immunity, and profitability of broilers. Journal of Advanced Veterinary and Animal Research 6: 66-73.

Leeson S and Caston L, 2008. Using minimal supplements of trace minerals as a method of reducing trace mineral content of poultry. Animal Feed Science and Technology 142: 339347. https://doi.org/10.1016/j.anifeedsci.2007.08.004

$\mathrm{Lu} \mathrm{L}$, Ji C, Luo XG, Liu B and Yu SX, 2006. The effect of supplemental manganese in broilers diets on abdominal fat deposition and meat quality. Animal Feed Science and Technology 129: 49-59. https://doi.org/10.1016/j. anifeedsci.2005.12.005

M'Sadeq SA, Wu SB, Choct M and Swick RA, 2018. Influence of trace mineral sources on broiler performance, lymphoid organ weights, apparent digestibility, and bone mineralization. Poultry Science 97: 3176-3182. https://doi.org/10.3382/ps/pey 197 
Ma W, Niu H, Feng J, Wang Y and Feng J, 2011. Effects of zinc glycine chelate on oxidative stress, contents of trace elements, and intestinal morphology in broilers. Biological Trace Element Research 142: 546-556. https://doi.org/ 10.1007/s12011-010-8824-9

Madkour M, Ali HM, Yassein SA, Abdel-Fattah SA, El-Allawy HM and El-Wardany I, 2015. Effect of dietary organic selenium supplement on growth and reproductive performance of Japanese quail breeders and their progeny and its relation to antioxidation and thyroid activity. International Journal of Poultry Science 14: 317-324. https://dx.doi.org/10.3923/ijps.2015.317.324

Mishra SK, Swain RK, Behura NC, Das A, Mishra A, Sahoo G and Dash AK, 2013. Effect of supplementation of organic minerals on the performance of broilers. The Indian journal of Animal Sciences 83: 1335-1339.

Monteagudo MD, Hernandez ER, Seco C, Gonzalez-Riola J, Revilla M, Villa LF and Rico H, 1997. Comparison of the bone robusticity index and bone weight/bone length index with the results of bone densitometry and bone histomorphometry in experimental studies. Acta Anatomica (Basel) 160: 195-199. https://doi.org/10.1159/000148011

Nollet L, Van der klis JD, Lensing M and Spring P, 2007. The Effect of replacing inorganic with organic trace minerals in broiler diets on productive performance and mineral excretion. Journal of Applied Poultry Research 16: 592-597. https://doi.org/10.3382/japr.2006-00115

NRC, 1994. Nutrient Requirements of Poultry. $9^{\text {th }}$ Ed (Revised), National Academy Press, Washington, DC, USA.

Nys Y, Schlegel P, Durosoy S, Jondreville C and Narcy A, 2018. Adapting trace mineral nutrition of birds for optimising the environment and poultry product quality. World's Poultry Science Journal 74: 225-238. https://doi.org/10.1017/ $\underline{\text { S0043933918000016 }}$

Pacheco BHC, Nakagi VS, Kobashigawa EH, Caniatto ARM, Faria DE and Pacheco BHC, 2017. Dietary levels of zinc and manganese on the performance of broilers between 1 to 42 days of age. Revista Brasileira de Ciência Avícola 19: 171178. https://doi.org/10.1590/1806-9061-2016-0323

Parsaie S, Shariatmadari F, Zamiri MJ and Khajeh K, 2007. Influence of wheat-based diets supplemented with xylanase, bile acid and antibiotics on performance, digestive tract measurements and gut morphology of broilers compared with a maize-based diet. British Poultry Science 48: 594600. https://doi.org/10.1080/00071660701615788

Rajkumar U, Vinoth A, Reddy PK, Shanmugam E, Rama M and Rao SV, 2018. Effect of supplemental trace minerals on Hsp70 mRNA expression in commercial broiler chicken. Animal Biotechnology 29: 20-25. https://doi.org/10.1080/ 10495398.2017.1287712

Riesenfeld A, 1972. Metatarsal robusticity in bipedal rats. American Journal of Physical Anthropology 36: 229-233. https://doi.org/10.1002/ajpa.1330360211

Rossi P, Rutz F, Anciuti MA, Rech JL and Zauk NHF, 2007. Influence of graded levels of organic zinc on growth performance and carcass traits of broilers. Journal of Applied Poultry Research 16: 219-225. https://doi.org/10.1093/ japr/16.2.219

Salim HM, Lee HR, Jo C, Lee SK and Lee BD, 2012. Effect of sex and dietary organic zinc on growth performance, carcass traits, tissue mineral content, and blood parameters of broiler chickens. Biological Trace Element Research 147: 120-129. https://doi.org/10.1007/s12011-011-9282-8

SAS, 1994. SAS/STAT®User's Guide: Statistics Ver. 6.04, $4^{\text {th }}$ Ed. SAS Institute Inc., Cary, NC.

Seedor JG, Quartuccio HA and Thompson DD, 1991. The bisphosphonate alendronate (MK-217) inhibits bone loss due to ovariectomy in rats. Journal of Bone and Mineral Research 6: 339-346. https://doi.org/10.1002/jbmr.5650060

Shamoto K and Yamauchi K, 2000. Recovery responses of chick intestinal villus morphology to different refeeding procedures. Poultry Science 79: 718-723. https://doi.org/ $10.1093 / \mathrm{ps} / 79.5 .718$

Sirri F, Maiorano G, Tavaniello S, Chen J, Petracci M and Meluzzi A, 2016. Effect of different levels of dietary zinc, manganese, and copper from organic or inorganic sources on performance, bacterial chondronecrosis, intramuscular collagen characteristics, and occurrence of meat quality defects of broiler chickens. Poultry Science 95: 1813-1824. https://doi.org/10.3382/ps/pew064

Sun X, McElroy A, Webb Jr KE, Sefton AE and Novak C, 2005. Broiler performance and intestinal alterations when fed drug-free diets. Poultry Science 84: 1294-1302. https://doi.org/10.1093/ps/84.8.1294

Sunder GS, Kumar CV, Panda AK, Raju MVLN and Rao SVR, 2013. Effect of supplemental organic $\mathrm{Zn}$ and $\mathrm{Mn}$ on broiler performance, bone measures, tissue mineral uptake and immune response at 35 days of age. Current Research in Poultry Science 3: 1-11. https://dx.doi.org/10.3923/crpsaj. 2013.1.11

Tomaszewska E, Muszyński S, Dobrowolski P, Kwiecień M, Winiarska-Mieczan A, Świetlicka I and Wawrzyniak A, 2017. Effect of zinc level and source (zinc oxide vs. zinc glycine) on bone mechanical and geometric parameters, and histomorphology in male Ross 308 broiler chicken. Brazilian Journal of Poultry Science 19: 159-170. https://doi.org/ 10.1590/1806-9061-2016-0285

William JB and Linda MB, 2000. Color atlas of veterinary histology. $2^{\text {nd }}$ Ed. Lippincott Williams \& Wilkins, Hoboken, USA.

Yalcin S, Ozkan S, Coskuner E, Bilgen G, Delen Y, Kurtulmus Y and Tanyalcin T, 2001. Effects of strain, maternal age and sex on morphological characteristics and composition of tibial bone in broilers. British Poultry Science 42: 184-190. https://doi.org/10.1080/00071660120048429

Yildiz AO, Cufadar Y and Olgun O, 2011. Effects of dietary organic and inorganic manganese supplementation on performance, egg quality and bone mineralisation in laying hens. Revue de Medecine Veterinaire 10: 482-488.

Zakaria HA, Jalal M, AL-Titi HH and Souad A, 2017. Effect of sources and levels of dietary zinc on the performance, carcass traits and blood parameters of broilers. Brazilian Journal of Poultry Science 19: 519-526. https://doi.org/ 10.1590/1806-9061-2016-0415

Zhao J, Shirley RB, Vazquez-anon M, Dibner J, Richards P, Fisher T, Hampton T, Christensen KD, Allard JP and Giesen AP 2010. Effects of chelated of trace elements: on growth performance, breast meat yield and footpad health in commercial meat broilers. Journal of Applied Poultry Research 19: 365-372. https://doi.org/10.3382/japr.2009-00020 